\title{
Synthesis of Both Enantiomers of Altholactone, Isoaltholactone and 5-Hydroxygoniothalamin from Tri- $O$-acetyl-D-glucal, and Their Biological Activities ${ }^{1}$
}

\author{
Akira Hiratate, Hiromasa Kiyota, ${ }^{*}$ Toshiro Noshita, Ryo Takeuchi \\ and Takayuki ORITANI \\ Department of Applied Bioorganic Chemistry, Division of Life Science, Graduate School of Agricultural \\ Science, Tohoku University. 1-1 Tsutsumidori-Amamiya, Aoba-ku. Sendai 981-8555, Japan
}

(Received March 12, 2001 ; Accepted July 9, 2001)

\begin{abstract}
Both enantiomers of altholactone, isoaltholactone and 5-hydroxygoniothalamin were synthesized from tri- $O$-acetyl-D-glucal, and biological activities of altholactones were examined. For brine shrimp, the configuration of 3-hydroxy group at convex site was important for lethal activity, while $(2 S, 3 S)$ configuration was inhibitory to lettuce germination.
\end{abstract}

Key words: altholactone, isoaltholactone, 5-hydroxygoniothalamin, total synthesis, tri- $O$-acetyl-Dglucal.

\section{INTRODUCTION}

In the preceding paper, ${ }^{1)}$ we described the synthesis of $(-)$-ent-altholactone $[(-)-1],(-)$-ent-isoaltholactone $[(-)-2]$, and their trans-fused diastereomers from 2 , 3- $O$-cyclohexylidene-D-glyceraldehyde. However, the total yield of each compound was not satisfactory. To improve the synthesis and to compare their biological activities with natural enantiomers, we reinvestigated the synthesis of $\mathbf{1}$ and $\mathbf{2}$. Recently, we reported the improved method of phenolic Ferrier rearrangement reaction to prepare aryl $O-\Delta^{2}$-glycosides, ${ }^{2,3)}$ so we adopted this method to synthesize altholactones through a biomimetic route postulated by Sam et al. ${ }^{4}$ via 5hydroxygoniothalamin (3), which was isolated from the stem bark of Goniothalamus dolichocarpus. ${ }^{5)}$ In this paper, we report the synthesis of these compounds.

\footnotetext{
* To whom correspondence should be addressed.

${ }^{1}$ This work was carried out under a proposal and supervision of the late Dr. Takeyoshi Sugiyama, who passed away on September 5, 1999 at 53 years of age. This paper is dedicated to his memory.

Abbreviations: DEAD, diethyl azodicarboxylate; PPTS, pyridinium $p$-toluenesulfonate; THP, tetrahydropyranyl; PTLC, preparative thin layer chromatography; NOBA, $m$-nitrobenzyl alcohol; $\operatorname{Ag}(\mathrm{DPAH})_{2}$, silver dipicolinate; $\mathrm{CC}$, column chromatography; THF, tetrahydrofuran; MP, $p$ methoxyphenyl
}

\section{MATERIALS AND METHODS}

\section{General}

$\mathrm{Mp}$ values are uncorrected. Optical rotation (in $\mathrm{CHCl}_{3}$, unless otherwise noted); Jasco DIP-4. IR spectra; Jasco IR-810. ${ }^{1} \mathrm{H}$ NMR; Jeol JNM GSX-270 ( $\delta_{\mathrm{TMS}}^{\mathrm{CDCl} / 3}$ ppm), $J$ values are given in Hertz $(\mathrm{Hz})$. Mass spectra (FAB); JEOL DX-303HF. CC; $\mathrm{SiO}_{2}$.

\section{Synthesis of Compounds}

2.1 (2R,5S,6R)-6-(Benzoyloxy)methyl-5,6-dihydro-2(4'-methoxyphenoxy)-2H-pyran-5-ol. (6)

In the same manner as described in lit., ${ }^{1)} \mathbf{5}^{6)}(9.00 \mathrm{~g}$, $35.7 \mathrm{mmol})$ was converted to $6(11.7 \mathrm{~g}, 32.8 \mathrm{mmol}, 92 \%)$ as colorless needles, $\mathrm{mp} 97^{\circ} \mathrm{C},[\alpha]_{\mathrm{D}}^{20}+61.4^{\circ}(c=0.360)$, IR $\nu_{\max }^{\mathrm{KBr}} \mathrm{cm}^{-1}: 3480(\mathrm{O}-\mathrm{H}), 1690(\mathrm{C}=\mathrm{O}), 1490,{ }^{1} \mathrm{H}$ NMR $\delta: 2.42(1 \mathrm{H}$, br. s, OH), $3.74(3 \mathrm{H}, \mathrm{s}, \mathrm{Me}), 4.13(1 \mathrm{H}, \mathrm{ddd}$, $J=3.0,5.2,9.3,6-\mathrm{H}), 4.19(1 \mathrm{H}$, dddd, $J=1.5,2.7,6.6$, 9.3, 5-H), $4.53(1 \mathrm{H}, \mathrm{dd}, J=2.0,12.0, \mathrm{CH} H \mathrm{O}), 4.71(1 \mathrm{H}$, $\mathrm{dd}, J=5.2,12.0, \mathrm{C} H \mathrm{HO}), 5.58(1 \mathrm{H}, \mathrm{d}, J=2.2,2-\mathrm{H}), 5.94$ ( $1 \mathrm{H}$, ddd, $J=2.2,2.7,10.3,4-\mathrm{H}), 6.11(1 \mathrm{H}$, pseudo d, $J=10.3,3-\mathrm{H}), 6.7-8.0$ (9H, m, Ar). Found: C, 67.23; H, 5.59, Calcd. for $\mathrm{C}_{20} \mathrm{H}_{20} \mathrm{O}_{6}: \mathrm{C}, 67.40 ; \mathrm{H}, 5.66 \%$.

2.2 (2R,5S,6R)-6-(Benzoyloxy)methyl-5,6-dihydro-2(4'-methoxyphenoxy)-5-(tetrahydropyran-2"-yl) oxy-2H-pyran. (7)

A solution of $6(4.20 \mathrm{~g}, 11.7 \mathrm{mmol}), 3$,4-dihydro- $2 \mathrm{H}$ pyran $(1.5 \mathrm{~g})$ and PPTS $(10 \mathrm{mg})$ in $\mathrm{CH}_{2} \mathrm{Cl}_{2}(30 \mathrm{ml})$ was stirred at $0^{\circ} \mathrm{C}$ for $6 \mathrm{hr}$. This was poured into aq. 
$\mathrm{NaHCO}_{3}$, extracted with $\mathrm{CH}_{2} \mathrm{Cl}_{2}$, washed with brine, dried $\left(\mathrm{MgSO}_{4}\right)$ and concentrated in vacuo. $\mathrm{CC}$ (hexane/EtOAc) gave $7(5.00 \mathrm{~g}, 11.3 \mathrm{mmol}, 97 \%)$ as a colorless oil. IR $\nu_{\max }^{\text {flim }} \mathrm{cm}^{-1}: 1720(\mathrm{C}=\mathrm{O}), 1500 .{ }^{1} \mathrm{H}$ NMR $\delta$ : 1.48-1.88 [6H, m, $\left.\left(\mathrm{CH}_{2}\right)_{3}\right], 3.46-3.57(2 \mathrm{H}, \mathrm{m}), 3.72$ and 3.74 (total $3 \mathrm{H}$, each s, Me), 3.75-4.02 $(2 \mathrm{H}, \mathrm{m}), 4.21-4.56$ $(2 \mathrm{H}, \mathrm{m}), 4.88(1 \mathrm{H}, \mathrm{dd}, J=3.7,5.6), 5.59(1 \mathrm{H}, \mathrm{br} . \mathrm{s}, 2-\mathrm{H})$, 5.93 and 5.99 (total $1 \mathrm{H}$, each ddd, $J=2.0,3.9,10.3,4-\mathrm{H}$ ), 6.19 and 6.29 (total $1 \mathrm{H}$, each dd, $J=1.0,10.3,3-\mathrm{H}$ ), 6.7$7.1(4 \mathrm{H}, \mathrm{m}, \mathrm{Ar}), 7.3-8.1$ (5H, m, Ar). HRMS (PEG+ NOBA) $m / z: 463.1734$; Calcd. for $\left(\mathrm{C}_{25} \mathrm{H}_{28} \mathrm{O}_{7}+\mathrm{Na}\right)^{+}$, 463.1733 .

$2.3(2 R, 5 S, 6 R)-5,6-D i h y d r o-6-h y d r o x y m e t h y l-2-$ (4'-methoxyphenoxy)-5-(tetrahydropyran-2"-yl) oxy-2H-pyran. (8)

Similarly to $5,7(5.00 \mathrm{~g}, 11.3 \mathrm{mmol})$ gave $8(3.80 \mathrm{~g}$, $11.3 \mathrm{mmol}$, quant.) as a colorless oil. IR $\nu_{\max }^{\text {fllm }} \mathrm{cm}^{-1}: 3460$ $(\mathrm{O}-\mathrm{H}), 1505 .{ }^{1} \mathrm{H}$ NMR $\delta: 1.5-1.9\left[6 \mathrm{H}, \mathrm{m},\left(\mathrm{CH}_{2}\right)_{3}\right], 1.65$ $(0.5 \mathrm{H}$, br. s, OH $), 2.58(0.5 \mathrm{H}, \mathrm{dd}, J=6.1,7.3, \mathrm{OH}), 3.55$ $(1 \mathrm{H}, \mathrm{m}), 3.67-4.01(4 \mathrm{H}, \mathrm{m}), 3.78(3 \mathrm{H}, \mathrm{s}, \mathrm{Me}), 4.30$ and 4.42 (total $1 \mathrm{H}$, each ddd, $J=1.5,4.9,9.4,5-\mathrm{H}), 4.72-4.77$ $(1 \mathrm{H}, \mathrm{m}), 5.56(1 \mathrm{H}$, br. s, $2-\mathrm{H}), 5.87$ and 5.91 (total $1 \mathrm{H}$, each ddd, $J=2.2,4.9,10.4,4-\mathrm{H}$ ), 6.14 and 6.27 (total $1 \mathrm{H}$, each d, $J=10.4,3-\mathrm{H}), 6.8-7.4(4 \mathrm{H}, \mathrm{m}, \mathrm{Ar})$. Found: C, 63.75; H, 7.04, Calcd. for $\mathrm{C}_{18} \mathrm{H}_{24} \mathrm{O}_{6}: \mathrm{C}, 64.27 ; \mathrm{H}, 7.19 \%$.

2.4 (2R,5S, 6R, 3E)-5,6-Dihydro-2-(4'-methoxyphenoxy)-6-(2"-phenylethenyl)-5-(tetrahydropyran$\left.2^{\prime \prime \prime}-y l\right)$ oxy-2H-pyran [(5S,6R)-9]

In the same manner as described in lit., ${ }^{1)} \mathbf{8}(3.80 \mathrm{~g}, 11.3$ mmol) gave aldehyde, which was coupled with $\mathrm{Ph}_{3} \mathrm{P}=$ $\mathrm{CHPh}$ to give $(5 S, 6 R)-9(2.9 \mathrm{~g}, 7.1 \mathrm{mmol}, 63 \%)$ as a colorless oil. IR $\nu_{\max }^{\text {film }} \mathrm{cm}^{-1}: 1505 .{ }^{1} \mathrm{H}$ NMR $\delta: 1.4-1.9$ $\left[6 \mathrm{H}, \mathrm{m},\left(\mathrm{CH}_{2}\right)_{3}\right], 3.50(1 \mathrm{H}, \mathrm{m}), 3.76$ and 3.77 (total $3 \mathrm{H}$, each s, Me), $3.90(1 \mathrm{H}, \mathrm{m}), 4.12$ and $4.26($ total $1 \mathrm{H}$, each ddd, $J=1.7,3.0,9.4,5-\mathrm{H}$ ), 4.56 and 4.59 (total $1 \mathrm{H}$, each dd, $J=6.2,9.4,6-\mathrm{H}), 4.70(0.5 \mathrm{H}, \mathrm{dd}, J=3.9,4.4), 4.96$ $(0.5 \mathrm{H}, \mathrm{t}, J=3.1), 5.57(1 \mathrm{H}$, br. s, $2-\mathrm{H}), 5.92$ and 5.97 (total $1 \mathrm{H}$, each ddd, $J=1.9,3.1,10.2,4-\mathrm{H}$ ), 6.19 and 6.24 (total $1 \mathrm{H}$, each $\mathrm{dd}, J=1.5,10.2,3-\mathrm{H}$ ), 6.25 and 6.39 (total $1 \mathrm{H}$, each dd, $\left.J=6.2,16.1,1^{\prime \prime}-\mathrm{H}\right), 6.70(1 \mathrm{H}, \mathrm{d}, J=$ 16.1, 2"-H), 6.8-7.4 (9H, m, Ar). HRMS (PEG+ NOBA) $m / z: 431.1836$; Calcd. for $\left(\mathrm{C}_{25} \mathrm{H}_{28} \mathrm{O}_{5}+\mathrm{Na}\right)^{+}$, 431.1834 .

2.5 (5S, 6R, 3E)-5, 6-Dihydro-6-(2'-phenylethenyl)5-(tetrahydropyran-2"-yl)oxy-2H-pyran-2-one [(5S,6R)-10)]

A solution of $(5 S, 6 R)-9(2.9 \mathrm{~g}, 7.1 \mathrm{mmol}), \mathrm{Ag}$ $(\text { DPAH })_{2}(10.0 \mathrm{~g}, 21.8 \mathrm{mmol})$ in $\mathrm{MeCN} / \mathrm{H}_{2} \mathrm{O}(4: 1,50 \mathrm{ml})$ was stirred at $20^{\circ} \mathrm{C}$ for $0.5 \mathrm{hr}$. The mixture was filtered, and the filtrate was poured into aq. $\mathrm{Na}_{2} \mathrm{~S}_{2} \mathrm{O}_{3}$ and extracted with ether. The extract was washed with brine, dried $\left(\mathrm{MgSO}_{4}\right)$ and concentrated in vacuo. CC (benzene/ EtOAc) gave hemiacetal $(2.0 \mathrm{~g}, 6.6 \mathrm{mmol}, 93 \%)$ as a colorless oil, IR $\nu_{\max }^{\text {film }} \mathrm{cm}^{-1}: 3400(\mathrm{O}-\mathrm{H})$. This crude hemiacetal was used in the next step without further purification.

A suspension of the oil $(1.5 \mathrm{~g}, 5.0 \mathrm{mmol})$ and activated $\mathrm{MnO}_{2}(30 \mathrm{~g})$ in $\mathrm{CH}_{2} \mathrm{Cl}_{2}(30 \mathrm{ml})$ was shaken at $20^{\circ} \mathrm{C}$ for $2 \mathrm{hr}$. The mixture was filtered through a Celite pad and the filtrate was concentrated in vacuo to give $(5 S, 6 R)-\mathbf{1 0}$ $(1.4 \mathrm{~g}, 4.7 \mathrm{~mol}, 94 \%)$ as a colorless oil. IR $\nu_{\max }^{\text {film }} \mathrm{cm}^{-1}$. $1730(\mathrm{C}=\mathrm{O}) .{ }^{1} \mathrm{H}$ NMR $\delta: 1.5-1.9\left[6 \mathrm{H}, \mathrm{m},\left(\mathrm{CH}_{2}\right)_{3}\right], 3.5-$ $3.6\left(1 \mathrm{H}, \mathrm{m}, 6^{\prime \prime}-\mathrm{H}\right), 3.8-3.95\left(1 \mathrm{H}, \mathrm{m}, 6^{\prime \prime}-\mathrm{H}\right), 4.37(0.5 \mathrm{H}$, ddd, $J=1.7,2.7,8.0,5-\mathrm{H}), 4.45(0.5 \mathrm{H}$, ddd, $J=1.2,3.2$, $6.8,5-\mathrm{H}), 4.73\left(0.5 \mathrm{H}, \mathrm{dd}, J=2.9,4.2,2^{\prime \prime}-\mathrm{H}\right), 4.89(0.5 \mathrm{H}$, dd, $J=2.9,2.9,2^{\prime \prime}-\mathrm{H}$ ), 4.99 and 5.13 (total $1 \mathrm{H}$, each ddd, $J=1.4,6.7,7.4,6-\mathrm{H}$ ), 6.04 and 6.11 (total $1 \mathrm{H}$, each dd, $J=1.5,10.0,3-\mathrm{H}$ ), 6.22 and 6.26 (total $1 \mathrm{H}$, each dd, $J=$ $\left.6.7,16.1,1^{\prime}-\mathrm{H}\right), 6.78$ and 6.79 (total $1 \mathrm{H}$, each dd, $J=1.5$, $16.1,2^{\prime}-\mathrm{H}$ ), 6.90 and 6.98 (total $1 \mathrm{H}$, each $\mathrm{dd}, J=3.0$, 10.0, 4-H), 7.2-7.4 (5H, m, Ar).

\section{$2.6 \quad(5 S, 6 S)-10$}

A solution of $(5 S, 6 R)-10(1.4 \mathrm{~g}, 4.7 \mathrm{mmol}), 1 \mathrm{~N} \mathrm{NaOH}$ $(4.8 \mathrm{ml})$ in 1,4-dioxane $/ \mathrm{H}_{2} \mathrm{O}(1: 1,20 \mathrm{ml})$ was stirred at $0{ }^{\circ} \mathrm{C}$ for $0.5 \mathrm{hr}$. The mixture was acidified with dil. $\mathrm{HCl}$ and extracted with EtOAc. The extract was washed with brine, dried $\left(\mathrm{MgSO}_{4}\right)$ and concentrated in vacuo. To the residual oil and $\mathrm{Ph}_{3} \mathrm{P}(1.3 \mathrm{~g}, 5.0 \mathrm{mmol})$ in THF $(30 \mathrm{ml})$ was added DEAD $(0.80 \mathrm{ml}, 5.0 \mathrm{mmol})$ at $-20^{\circ} \mathrm{C}$ under $\mathrm{N}_{2}$ and the mixture was stirred at this temp. for $10 \mathrm{hr}$. The reaction mixture was concentrated in vacuo and $\mathrm{CC}\left(\mathrm{CH}_{2} \mathrm{Cl}_{2} / \mathrm{EtOAc}\right)$ gave $(5 S, 6 S)-\mathbf{1 0}$ $(0.59 \mathrm{~g}, 42.0 \mathrm{~mol}, 42 \%)$ as a colorless oil. IR $\nu_{\max }^{\text {film }} \mathrm{cm}^{-1}$ : $1725(\mathrm{C}=\mathrm{O}) .{ }^{1} \mathrm{H}$ NMR $\delta: 1.5-1.9\left[6 \mathrm{H}, \mathrm{m},\left(\mathrm{CH}_{2}\right)_{3}\right], 3.5$ $\left(1 \mathrm{H}, \mathrm{m}, 6^{\prime \prime}-\mathrm{H}\right), 3.8\left(1 \mathrm{H}, \mathrm{m}, 6^{\prime \prime}-\mathrm{H}\right), 4.25$ and 4.46 (total $1 \mathrm{H}$, each dd, $J=3.7,5.1,5-\mathrm{H}), 4.74\left(0.5 \mathrm{H}, \mathrm{t}, J=3.3,2^{\prime \prime}-\mathrm{H}\right)$, $4.82\left(0.5 \mathrm{H}, \mathrm{t}, J=2.9,2^{\prime \prime}-\mathrm{H}\right), 5.06$ and 5.14 (total $1 \mathrm{H}$, each ddd, $J=1.2,3.7,7.0,6-\mathrm{H}$ ), 6.14 and 6.18 (total $1 \mathrm{H}$, each $\mathrm{d}, J=9.8,3-\mathrm{H}$ ), 6.38 and 6.51 (total $1 \mathrm{H}$, each dd, $J=7.0$, $\left.16.1,1^{\prime}-\mathrm{H}\right), 6.78\left(1 \mathrm{H}, \mathrm{dd}, J=1.2,16.1,2^{\prime}-\mathrm{H}\right), 7.02(1 \mathrm{H}$, $\mathrm{dd}, J=5.1,9.8,4-\mathrm{H}), 7.25-7.45(5 \mathrm{H}, \mathrm{m}, \mathrm{Ar})$.

2.7 (5S, 6S, 3E)-5,6-Dihydro-5-hydroxy-6-(2'-phenylethenyl)-2H-pyran-2-one [5-hydroxygoniothalamin, $(+)-3]$

A suspension of $(5 S, 6 S)-10(0.50 \mathrm{~g}, 1.7 \mathrm{mmol})$ and Amberlyst- 15 in dry $\mathrm{MeOH}(20 \mathrm{ml})$ was stirred at $20^{\circ} \mathrm{C}$ for $4 \mathrm{hr}$. The mixture was filtered and the filtrate was concentrated in vacuo. CC (hexane/ether) gave (+)-3 (0. $35 \mathrm{~g}, 1.6 \mathrm{~mol}, 89 \%)$ as colorless plates, $\mathrm{mp} 113-114^{\circ} \mathrm{C}$, $[\alpha]_{\mathrm{D}}^{20}+252^{\circ}(c=0.50)$ (natural; lit., ${ }^{5)} \mathrm{mp} 98^{\circ} \mathrm{C},[\alpha]_{\mathrm{D}}^{20}+$ $79^{\circ}(c=0.2)$. synthetic; lit., ${ }^{7}$ oil, $[\alpha]_{\mathrm{D}}^{21}+62.4^{\circ}(c=0.12$, $\left.\mathrm{CH}_{2} \mathrm{Cl}_{2}\right)$ \}. Spectral data were identical with those reported. Found: $\mathrm{C}, 71.97 ; \mathrm{H}, 5.48$, Calcd. for $\mathrm{C}_{13} \mathrm{H}_{12} \mathrm{O}_{3}$ : C, $72.21 ; \mathrm{H}, 5.55 \%$.

$2.8(2 R, 3 R, 3 a S, 7 a S)-3-H y d r o x y-2-p h e n y l-2,3,3 a, 7 a-$ tetrahydro-5H-furo $[3,2 b]$ pyran-5-one $[(+)$ altholactone, $(+)-1)]$ and its $(2 S, 3 S, 3 a S, 7 a S)$ isomer $[(+)$-isoaltholactone, $(+)-2]$

To a solution of $(+)-3(0.10 \mathrm{~g}, 0.46 \mathrm{mmol})$ and vanadyl acetylacetonate $(10 \mathrm{mg})$ in dry benzene $(25 \mathrm{ml})$ 
was added dropwise $5 \mathrm{M} t$-BuOOH in toluene $(0.12 \mathrm{ml}$, $0.60 \mathrm{mmol}$ ) under $\mathrm{N}_{2}$ and the mixture was stirred for 1 day at $40^{\circ} \mathrm{C}$. After being cooled to $20^{\circ} \mathrm{C}$, the mixture was poured into aq. $\quad \mathrm{Na}_{2} \mathrm{~S}_{2} \mathrm{O}_{3}$ and extracted with ether. The extract was washed with brine, dried $\left(\mathrm{MgSO}_{4}\right)$ and concentrated in vacuo. The crude oil was treated with Amberlyst- 15 in $\mathrm{CH}_{2} \mathrm{Cl}_{2}(20 \mathrm{ml})$ for $2 \mathrm{hr}$. Then the mixture was filtered and the filtrate was concentrated in vacuo. PTLC (hexane/ether $=1: 2$ ) and recrystallization (hexane/ether) gave (+)-1 (23 mg, $0.10 \mathrm{mmol}, 22 \%)$ as an oil and $(+)-2(46 \mathrm{mg}, 0.20 \mathrm{mmol}, 44 \%)$ as colorless needles. $(+)-1,[\alpha]_{\mathrm{D}}^{20}+182^{\circ}(c=0.550)$ (see lit. $\left.{ }^{1)}\right) .(+)-2$, $\mathrm{mp} 107^{\circ} \mathrm{C},[\alpha]_{\mathrm{D}}^{20}+55^{\circ}(c=0.50)$ (see lit. $\left.{ }^{1)}\right)$.

2.9 (2R, 5S, 6R, 3E)-5, 6-Dihydro-2-(4' - methoxyphenoxy)-6-(2"-phenylethenyl)-2H-pyran-5-ol [(5S,6R)-11)]

In the similar manner as the conversion of $(5 S, 6 S)-\mathbf{1 0}$ to $(+)-3,(5 S, 6 R)-9(1.7 \mathrm{~g}, 4.1 \mathrm{mmol})$ gave $(5 S, 6 R)-\mathbf{1 1}$ $(0.83 \mathrm{~g}, 2.5 \mathrm{mmol}, 63 \%)$ as colorless needles, $\mathrm{mp} 142^{\circ} \mathrm{C}$, $[\alpha]_{\mathrm{D}}^{20}+130^{\circ}(c=1.00)$. IR $\nu_{\max }^{\mathrm{KBr}} \mathrm{cm}^{-1}: 3440(\mathrm{O}-\mathrm{H}) .{ }^{1} \mathrm{H}$ NMR $\delta: 1.71(1 \mathrm{H}, \mathrm{d}, J=6.1, \mathrm{OH}), 3.76(3 \mathrm{H}, \mathrm{s}, \mathrm{Me}), 4.15$ $(1 \mathrm{H}, \mathrm{ddd}, J=2.2,6.1,9.0,5-\mathrm{H}), 4.42(1 \mathrm{H}, \mathrm{dd}, J=6.8$, $9.0,6-\mathrm{H}), 5.58(1 \mathrm{H}, \mathrm{d}, J=1.2,2-\mathrm{H}), 5.96(1 \mathrm{H}, \mathrm{dd}, J=2.2$, $10.3,4-\mathrm{H}), 6.15(1 \mathrm{H}, \mathrm{dd}, J=1.2,10.3,3-\mathrm{H}), 6.30(1 \mathrm{H}, \mathrm{dd}$, $\left.J=6.8,16.1,1^{\prime \prime}-\mathrm{H}\right), 6.75\left(1 \mathrm{H}, \mathrm{d}, J=16.1,2^{\prime \prime}-\mathrm{H}\right), 6.8-7.5$ $(9 \mathrm{H}, \mathrm{m}, \mathrm{Ar})$. Found: $\mathrm{C}, 73.90 ; \mathrm{H}, 6.22$, Calcd. for $\mathrm{C}_{20} \mathrm{H}_{20} \mathrm{O}_{4}$ : C, 74.05; H, 6.22\%.

2.10 (2R, 5S, 6R, 3E)-5, 6-Dihydro-2-(4'-methoxyphenoxy)-5-(4"-nitrobenzoyl)oxy-6-(2'"'-phenylethenyl)-2H-pyran (12)

To a solution of $(5 S, 6 R)-11(0.83 \mathrm{~g}, 2.5 \mathrm{mmol}), \mathrm{Ph}_{3} \mathrm{P}$ $(2.0 \mathrm{~g}, 7.6 \mathrm{mmol})$ and $p$-nitrobenzoic acid $(0.43 \mathrm{~g}, 2.5$ $\mathrm{mmol})$ in dry THF $(20 \mathrm{ml})$ was added DEAD $(0.40 \mathrm{ml}$, $2.5 \mathrm{mmol}$ ) at $0^{\circ} \mathrm{C}$ under $\mathrm{N}_{2}$. The mixture was stirred at $20^{\circ} \mathrm{C}$ for $3 \mathrm{hr}$ and concentrated in vacuo. $\mathrm{CC}\left(\mathrm{CH}_{2} \mathrm{Cl}_{2} /\right.$ EtOAc) and recrystallization (ether) gave $12(1.0 \mathrm{~g}, 2.1$ mol, $84 \%)$ as yellow plates, $\mathrm{mp} 138^{\circ} \mathrm{C},[\alpha]_{\mathrm{D}}^{20}-340^{\circ}(c=$ 1.00). IR $\nu_{\max }^{\mathrm{KBr}} \mathrm{cm}^{-1}: 1750(\mathrm{C}=\mathrm{O}), 1520,1500 .{ }^{1} \mathrm{H}$ NMR $\delta: 3.78(3 \mathrm{H}, \mathrm{s}, \mathrm{Me}), 5.10(1 \mathrm{H}, \mathrm{ddd}, J=1.5,2.5,5.6,6-\mathrm{H})$, $5.42(1 \mathrm{H}, \mathrm{dd}, J=2.5,5.4,5-\mathrm{H}), 5.77(1 \mathrm{H}, \mathrm{d}, J=2.9,2-\mathrm{H})$, $6.26\left(1 \mathrm{H}, \mathrm{dd}, J=5.6,16.1,1^{\prime \prime \prime}-\mathrm{H}\right), 6.31(1 \mathrm{H}, \mathrm{dd}, J=2.9$, $10.1,3-\mathrm{H}), 6.40(1 \mathrm{H}, \mathrm{dd}, J=5.4,10.1,4-\mathrm{H}), 6.77(1 \mathrm{H}, \mathrm{dd}$, $J=1.5,16.1,2$ '"'-H), 6.8-8.3 (13H, m, Ar). HRMS (NOBA) $m / z: 496.1372$; Calcd. for $\left(\mathrm{C}_{27} \mathrm{H}_{23} \mathrm{O}_{7}+\mathrm{Na}\right)^{+}$, 496.1372.

\section{$2.11(5 R, 6 R)-11$}

In the similar manner as the conversion of 5 to $\mathbf{6 , 1 2}$ $(1.0 \mathrm{~g}, 2.1 \mathrm{mmol})$ gave $(5 R, 6 R)-11(0.57 \mathrm{~g}, 1.7 \mathrm{mmol}$, $81 \%)$ as colorless needles, mp $82^{\circ} \mathrm{C},[\alpha]_{\mathrm{D}}^{20}-73.9^{\circ}(c=$ $1.00)$.

\section{$2.12(5 R, 6 R)-9$}

In the similar manner as the conversion of 6 to $7,(5 R$, $6 R)-11(0.57 \mathrm{~g}, 1.7 \mathrm{mmol})$ gave $(5 R, 6 R)-9(0.57 \mathrm{~g}, 1.4$ mmol, $87 \%)$ as a colorless oil.

\section{$2.13(5 R, 6 R)-10$}

Similarly to $(5 S, 6 R)-10,(5 R, 6 R)-\mathbf{9}(0.57 \mathrm{~g}, 1.4 \mathrm{mmol})$ gave $(5 R, 6 R)-10(0.37 \mathrm{~g}, 1.2 \mathrm{mmol}, 85 \%)$ as a colorless oil.

\subsection{4 ent-5-Hydroxygoniothalamin [(-)-ent-3]}

Similarly to $(+)-3,(5 R, 6 R)-10(0.37 \mathrm{~g}, 1.2 \mathrm{mmol})$ gave $(-)$-ent-3 $(0.22 \mathrm{~g}, 1.0 \mathrm{mmol}, 83 \%)$ as colorless plates, $\mathrm{mp}$ $113-114^{\circ} \mathrm{C},[\alpha]_{\mathrm{D}}^{20}-250^{\circ}(c=0.50)$.

2.15 ent-Altholactone $[(-)-e n t-1]$ and ent-isoaltholactone $[(-)$-ent-2]

Similarly to $(+)-1$ and $(+)-2,(-)$-ent $-3(0.10 \mathrm{~g}, 0.46$ mmol) gave (-)-ent-1 (21 mg, $0.090 \mathrm{mmol}, 20 \%), \mathrm{mp} 72$ ${ }^{\circ} \mathrm{C},[\alpha]_{\mathrm{D}}^{20}-190^{\circ}(c=0.50, \mathrm{EtOH})\left[\right.$ lit. $^{8}{ }^{8)}[\alpha]_{\mathrm{D}}-166^{\circ}(c=$ 0.5 , EtOH $)$; lit. $\left.{ }^{9}[\alpha]_{\mathrm{D}}^{22}-180.5^{\circ}(c=0.2, \mathrm{EtOH})\right]$; and $(-)-$ ent-2 (44 mg, $0.19 \mathrm{mmol}, 41 \%), \mathrm{mp} 107^{\circ} \mathrm{C},[\alpha]_{\mathrm{D}}^{20}-54^{\circ}$ $(c=0.50, \mathrm{EtOH})\left[\right.$ lit. $^{1)}{ }^{1)} \mathrm{mp} 106.5-107.5^{\circ} \mathrm{C},[\alpha]_{\mathrm{D}}-54.4^{\circ}$ $(c=0.500, \mathrm{EtOH})]$. These were separated by PTLC.

\section{Bioassays}

\subsection{Brine shrimp test}

Eggs of brine shrimp (Artemia salina) were incubated to hatch in $200 \mathrm{ml}$ of artificial sea water at $26^{\circ} \mathrm{C}$ for 2 days. About twenty larvae were transferred to sample tube. To this was added a solution of each test compound in aq. Tween $80(5 \%)$, and the total concentration was adjusted to $250 \mathrm{ppm}$. This mixture was incubated for 1.5 days at $22^{\circ} \mathrm{C}$ and the ratio of lethality was counted.

\subsection{Lettuce germination test}

This test was done according to the method reported by us. ${ }^{10)}$

\section{RESULTS AND DISCUSSION}

\section{Synthesis}

As shown in Scheme 1, tri- $O$-acetyl-D-glucal (4) was converted to $5^{2,3,6)}$ and the primary hydroxymethyl group was selectively benzoylated to give $\mathbf{6}$. The remaining secondary hydroxy group was protected as THP ether (7) and the benzoyl group was removed to afford $\mathbf{8}$. The hydroxy group of $\mathbf{8}$ was oxidized to aldehyde and elongated with benzylidene(triphenyl)phosphorane to give 9 . The geometry of the double bond was exclusively $E$. Then the MP group was removed with $\operatorname{Ag}(\mathrm{DPAH})_{2}{ }^{2,3}$ and the formed hemiacetal was oxidized to lactone $(5 S$, $6 R)$-10. Next the $6 S$-configuration was inverted as follows: hydrolysis of the lactone ring gave hydroxy acid, which recyclized via intramolecular Mitsunobu reaction to afford $(5 S, 6 S)-10$. Removal of the THP group afforded 5-hydroxygoniothalamin (3), which was submitted to epoxidation followed by acid treatment to give the desired natural altholactone (+)-1 and isoaltholactone (+)-2. These isomers were separated by PTLC and the total yields was $4.0 \%$ and $8.0 \%$, respectively in 7 steps.

We also synthesized the antipodes of altholactones. The key intermediate $(5 S, 6 R)-9$ was deprotected to give $(5 S, 6 R)-11$. Inversion of 5-position was achieved by 


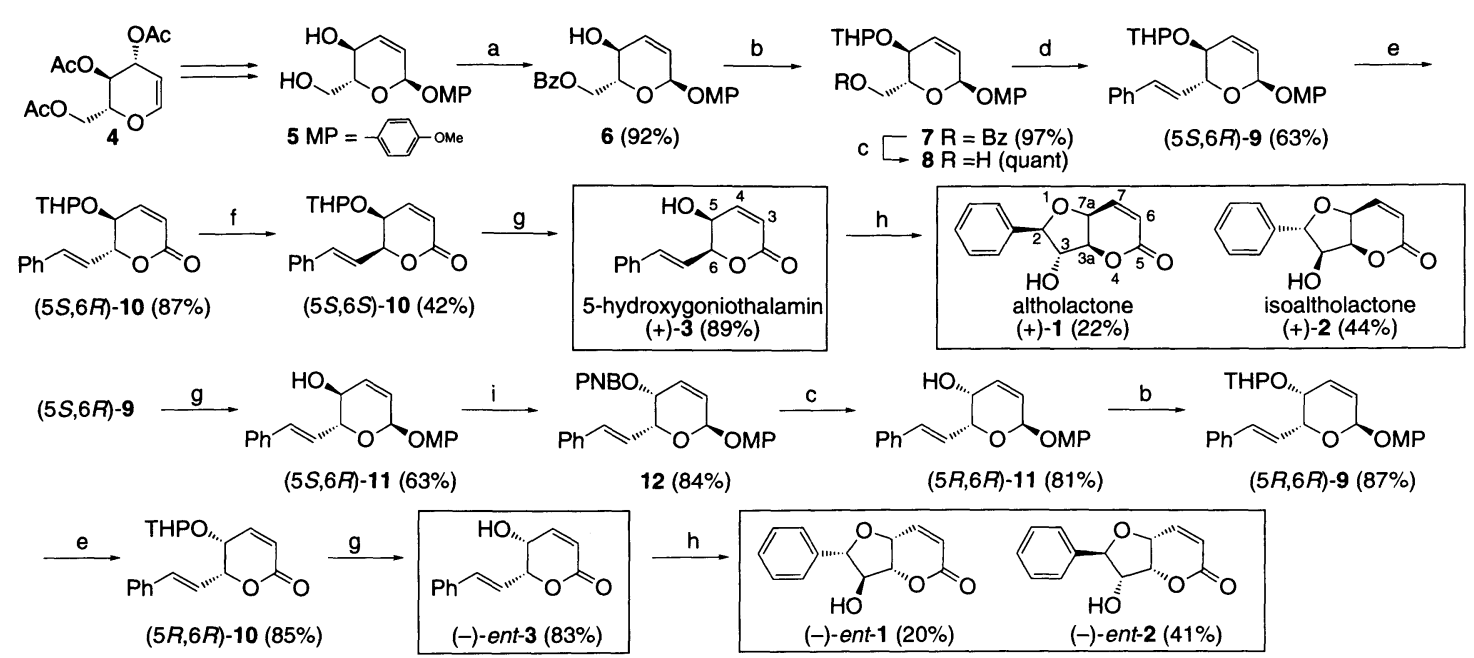

Scheme 1 Synthesis of compounds. a) benzoyl chloride, pyridine. b) DHP, PPTS. c) $\mathrm{K}_{2} \mathrm{CO}_{3}, \mathrm{MeOH}$. d) i. Swern oxi. ii. PhCH= $\mathrm{PPh}_{3}$. e) i. $\mathrm{Ag}(\mathrm{DPAH})_{2}, \mathrm{H}_{2} \mathrm{O}$ ii. $\mathrm{MnO}_{2}$. f) i. aq. $\mathrm{NaOH}$. ii. DEAD, $\mathrm{Ph}_{3} \mathrm{P}$. g) $\mathrm{H}^{+}, \mathrm{MeOH}$. h) i. vanadyl acetylacetonate, $t$-BuOOH. ii. $\mathrm{H}^{+}$. i) $p-\mathrm{NO}_{2} \mathrm{C}_{6} \mathrm{H}_{4} \mathrm{COOH}, \mathrm{DEAD}, \mathrm{PPh}_{3}$.

Mitsunobu reaction by using $p$-nitrobenzoic acid. (-)Ent-3, (-)-ent-1 and (-)-ent-2 were prepared from $(5 S$, $6 S)-11$ by the method similar to that for the natural isomers. The total yields of $(-)$-ent -1 and $(-)$-ent-2 were $3.0 \%$ and $6.1 \%$, respectively.

\section{Bioassays}

Since (+)-altholactone was isolated by monitoring the bioactivity with brine shrimp lethality, this test was applied for the synthetic altholactones. Inhibition of lettuce germination was also investigated. The $7 \mathrm{a}$ epimers with trans-fused ring were also tested. ${ }^{1)} \quad$ Table 1 shows the results of the brine shrimp test. Compounds $(+)-7 \mathrm{a}-$ epi-1, (+)-1, (-)-ent-1 and (-)-7a-epi-2 showed strong activity, while the activity of $(+)-2$ and (-)-ent-2 was low. This could be due to the difference in the orientation of the 3-hydroxy groups. Each 3hydroxy group of the former four active compounds was situated at the convex (sterically non-hindered) site of the

Table 1 Biological activities of the synthetic compounds.

\begin{tabular}{clcc}
\hline Entry & Compounds & $\begin{array}{c}\text { Death rate } \\
\text { (brine shimp) }\end{array}$ & $\begin{array}{c}\text { Germination rate } \\
\text { (lettuce) }\end{array}$ \\
\hline 1 & none & $5 \%$ & $75 \%$ \\
2 & $(+)-1$ & 40 & 50 \\
3 & $(-)-$ ent -1 & 31 & $5^{\mathrm{b}}$ \\
4 & $(+)-2$ & 13 & $25^{\mathrm{b}}$ \\
5 & $(-)-$ ent $^{\mathrm{2}}$ & 8 & 69 \\
6 & $(+)-7$ a-epi-1 & 63 \\
7 & $(-)-7 \mathrm{a}-$ epi-2 $^{\mathrm{a}}$ & 31 & $56^{\mathrm{b}}$ \\
\hline
\end{tabular}

a) Synthesis of these compounds are described in lit. ${ }^{1)}$

b) Elongation of the roots were strongly inhibited for the germinating seeds $(<10 \%$ compared with the control length). bicyclo[4.3.0] nonane ring. On the other hand, that of the latter was situated at the concave site and shielded by the ring. Consequently, this lethal activity was affected by the 3-hydroxy group and the configuration of other positions would not be important.

For the test of lettuce, the rates of germination were low for (-)-ent-1 and (+)-2. In addition, elongation of roots of the lettuce was strongly inhibited by $(-)-7 \mathrm{a}-$ epi-2. As a result, the compounds with $(2 S, 3 S)$ configuration showed the inhibitory activity for lettuce germination.

\section{REFERENCES}

1) A. Hiratate, H. Kiyota \& T. Oritani: J. Peticide Sci. 26, 361 (2001)

2) T. Noshita, T. Sugiyama, Y. Kitazumi \& T. Oritani: Tetrahedron Lett. 35, 8259 (1994)

3) T. Noshita, T. Sugiyama, Y. Kitazumi \& T. Oritani: Biosci. Biotech. Biochem. 59, 2052 (1995)

4) T. W. Sam, C.-S. Yeu, S. Matsjeh, E. K. Gan, D. Razak \& A. L. Mohamed: Tetrahedron Lett. 28, 2541 (1987)

5) S. H. Goh, G. C. L. Ee, C. H. Chuah \& T. C. W. Mak: Nat. Prod. Lett. 5, 255 (1995)

6) T. Sugai, H. Okazaki, A. Kuboki \& H. Ohta: Bull. Chem. Soc. Jpn. 70, 2535 (1997)

7) J. M. Harris \& G. A. O’Doherty: Org. Lett. 2, 2983 (2000)

8) J. P. Gesson, J. C. Jacquesy \& M. Mondon: Tetrahedron Lett. 28, 3945 (1987)

9) J. G. Gillhouley \& T. K. M. Shing, J. Chem. Soc., Chem. Commun. 976 (1988)

10) J. Takehara, T. Oritani \& K. Yamashita: Agric. Biol. Chem. 55, 2939 (1991) 


\section{要 約}

トリーO-アセチル-D-グルカールを出発物質とする アルトラクトン, イソアルトラクトンおよび 5-ヒド ロキシゴニオタラーン両鏡像体の合成と生物活性

平舘 彰, 清田洋正, 野下俊郎, 竹内 亮, 折谷隆之 前報に続き,アルトラクトン, イソアルトラクトン, 5-七 ドロキシゴニオタラミンの両鏡像体の合成を行った.トリー O-アセチル-D-グルカールから得られたアセタールに必
要な側鎖を延長後, アセタールをラクトンに導き，立体化 学を修飾することにより，5-七ドロキシゴニオタラーンの 両鏡像体を得た．更にエポキシ化・酸処理によってアルト ラクトンとイソアルトラクトンの両鏡像体を合成した。ア ルトラクトンの 6 種の異性体の生物活性を測定した結果, 殺ブラインシュリンプテストでは， 3 位の水酸基が covex 面にある（立体的に空いている）化合物の活性が強かった。 レタス発芽においては $(2 S, 3 S)$ の立体を有する化合物が 発芽, 特に根の伸長に強い阻害効果を示した。 